\title{
PREPARING LAWYERS FOR THE TWENTY-FIRST CENTURY ${ }^{1}$
}

\section{WILLIAM TWINING*}

We are already preparing lawyers for the twenty-first century. Whether we are doing so as efficiently, as imaginatively or as professionally as we might is another matter. Higher education of any kind tends to be an expensive enterprise which, even from a purely utilitarian point of view, can only be justified as a long-term investment. Those who are currently undergraduates or who are undergoing professional training or apprenticeship, or who are learning by experience as fledgling practitioners will only be able properly to evaluate their basic education and training after the year 2000. Accordingly today's topic is concerned with the here and now.

In the first part of this paper I shall draw attention to a number of recent trends and developments in legal education in the Commonwealth that give some grounds for optimism. In the second part I shall argue for a concerted effort to foster realistic and enlightened expectations about their legal education among law students and young lawyers.

One hopes that a significant proportion of the current generation of law students and young lawyers will look back to the 1990s as a period of relative enlightenment in which some of the truisms of educators in the late twentieth century were transformed in a sustained way from pious aspirations into practical working principles. These truisms include the following: that education is a life-long enterprise; that most higher education should be selfeducation; that the main role of undergraduate education is learning how to learn; that standard distinctions between academic and practical, theory and practice, liberal and vocational are false 
dichotomies that are mischievous as well as misleading; and that any body of lawyers worth preserving must take seriously its claims to be a learned profession.

These truisms are part of the standard aspirational discourse of Law Day addresses, after-dinner speeches, public lectures and Commonwealth Law Conferences. But those who control recruitment, vocational training, professional examinations, and related matters, by their practice and example as well as their talk often send quite different messages to law students and intending lawyers. These contradictory messages include the following: that studying law is mainly a matter of acquiring knowledge; that coverage is more important than depth; that what legal subjects one covers in primary legal education is more important than whether they are good vehicles for intellectual training; and that one is finished with academic study, critical analysis and even reading as soon as one graduates ... that "theory" is something one grows out of about the age of twenty-one. Such ideas are almost the exact opposite of the noble aspirations enumerated above. Just because they are more often assumed in practices and attitudes than in public statements they can have a more direct and subversive influence on the expectations and attitudes of law students and intending lawyers than pious sermons. One purpose of this paper is to make a plea to those responsible for vocational training, professional examinations and above all recruitment to take seriously the content of the messages they communicate to the young and, where appropriate, to consider changing their tune.

\section{TRENDS AND DEVELOPMENTS}

First, the good news. During the past thirty years the discipline of law in the Commonwealth has been undergoing an unprecedented period of expansion, experimentation and development. It has been transformed from a small scale, cheap, low prestige subject into an unrecognisably more sophisticated, pluralist and ambitious enterprise.

A report prepared in 1984 by the Heads of University Law Schools in England (HULSC) and endorsed by the Heads of Polytechnic Law Schools and Heads of Scottish Law Schools provides a convenient starting-point for considering these changes. ${ }^{2}$ From the vantage-point of 1984 we identified a number of key 
trends and developments in our discipline in the period beginning in the early sixties and extending to the early nineties: a great increase in the scale of legal education at all levels, backed by steadily buoyant demand for opportunities to study law; a new pluralism in academic law, signalled by such phrases as socio-legal studies, law in context, law and development and clinical education; a diversification of types of undergraduate study through mixed degrees, sandwich courses, and degrees with a large foreign component, (but only relatively modest provision for part-time study outside the London external system). There was a substantial increase in the number of courses seen as standard or as part of the core of legal studies: for example, administrative law, company law, consumer law, welfare law, intellectual property, domestic civil liberties, international protection of human rights and, in the United Kingdom, the laws of the European Community. The computer age in law got off to a slow start and at first was perceived as being mainly relevant to information retrieval. In a few places clinical work found a modest place in undergraduate studies. Perhaps more important in the present context, beginning in Ghana and Nigeria in the sixties there developed what has sometimes been referred to as "the Gower model", ${ }^{3}$ that is a rather rigid structuring of professional legal education and training into three or four discrete stages: academic, vocational, apprenticeship and continuing ... although in most countries continuing legal education was still at a rudimentary level.

By 1984 further developments were predicted: greater emphasis on commercial subjects, including some interesting newcomers with a strong international flavour: transfer of technology, financial regulation, credit transfer and specialised aspects of international trade. Computer applications and implications were perceived to go beyond information retrieval to include expert systems and many aspects of office management. In the same year the Commonwealth Law Ministers included on their agenda the important subject of education about law for non-lawyers, which may prove to be one of the biggest growth areas of the 1990s.

Since 1984 a new series of buzz words and phrases signals the pace of change: critical legal studies, in-house trainers, distance learning, access to legal education and the legal profession, skills research, multidisciplinary practice, multinational practice, 
international mobility of lawyers, law teaching clinics, training the trainers, judicial studies, law and medicine, records management, and, of course, autopeiosis. ${ }^{4}$

Looking forward into the nineteen-nineties we can expect to hear a lot more about specialist certification, compulsory continuing legal education, and especially important in the Commonwealth, law in multi-lingual societies. ${ }^{5}$ It is perhaps also significant that in respect of human rights the nineteen nineties are being spoken of as the decade of implementation. Also important in the present context has been the very substantial shift from emphasis on acquisition of knowledge to development of skills at the vocational stage, illustrated by new courses pioneered in Canada and rapidly spreading to, for example, Australia, Hong Kong, Lesotho, New Zealand, and, in 1989, even to the Inns of Court in London.

Amid all these changes there have, of course, been some equally important continuities in attitudes and practices. Two are directly relevant to this paper: a revival of interest in general principles and the reassertion of some of the central values of classical liberal education. ${ }^{6}$

Several points are worth noting about these impressionistic lists. First, most of these trends were international. While there have, of course, been many local variants and differences in timing, most of these items should today at least be familiar as ideas to legal educators throughout the Commonwealth. We are fortunate to belong to a strong and vital international network in which news of new developments, experiments and ideas is rapidly disseminated.

Secondly, these developments have continued during more than a decade of financial cuts, squeezes and crises in higher education in most parts of the Commonwealth. Law has generally been better cushioned than most other disciplines. The reasons for this are complex, but the main factor has almost certainly been the extraordinarily high demand for legal studies. In most countries (India is perhaps the main exception) law is one of the most popular and prestigious subjects with the result that there is rarely a problem of unfilled places; and competition ensures that law departments attract a high proportion ... some would say a disproportionate share ... of the academically most promising (or most successful) school-leavers. There have, of course, been 
serious problems: the out-dated views that law is naturally a cheap subject and that it is not "developmentally relevant" still persist in some quarters, leading to endemic underfunding and other brakes on progress. ${ }^{7}$ Cuts and squeezes have made the recruitment and retention of law teachers increasingly difficult. In poorer countries many law faculties struggle to keep going in situations of appalling economic difficulties. Yet even in such countries law faculties often benefit from attracting an academic elite of highly motivated, relatively well-educated students. In an important sense legal education is demand-led and as a result the attitudes and expectations of its clients, the students, fundamentally affect the practice of the enterprise.

The main object of the English HULSC Report to which I have referred ${ }^{8}$ was to challenge outdated ideas about the financial needs of our discipline. Law has been traditionally treated as one of the cheapest subjects with poor staff-student ratios, library-bound (with no need for equipment other than books), and, in most countries standard academic salaries. The Report argued that many recent developments inevitably increase unit costs: access courses, clinical education and skills training are all labour-intensive; book prices have generally increased at a faster rate than inflation in a period when student spending-power has often decreased; new developments have increased needs for international travel, field research, sabbatical leave, modern technology, four or even five year degrees, all of which are relatively expensive. As was mentioned above, in many countries there is a serious problem of staffing where academic salaries have fallen behind other comparable occupations and the gap between the earnings of practitioners and academics has widened. The main conclusion of the HULSC report was that law remains one of the most costeffective disciplines, but perceptions of its financial needs have to be adjusted to take account of the changing nature of legal education, training and research. The same point applies to changing conceptions of continuing legal education.

Fourthly, many recent developments mandate a broader vision of legal education as an enterprise. At the conference to celebrate the twentieth anniversary of the Hong Kong University Law Faculty, I argued that the contemporary agenda of issues in legal education is expanding our perceptions of the scope of the 
enterprise and requires a rethinking of the role of law schools. ${ }^{9}$ Until recently most reports and discussions of the subject have focussed on law degrees and initial qualification of private practitioners (the primary school model). Academic lawyers have generally played only a marginal role in post-degree education. The new agenda includes not only continuing legal education and judicial training, but also law in schools, paraprofessional training, and increasing legal awareness in society as a whole. That this is not merely a peripheral extra for "outreach programmes", "service teaching” and token exercises in public relations is illustrated by recent trends in dissemination and education about human rights, where priority is being given to such matters as classes for women's groups, community education and the training of social workers and police and prison officers. My argument in that paper was that law schools, as the core institutions of any national system of legal education, need to move beyond the "primary school model" to be redesigned as multi-functional resource centres for providing and assisting legal education at all levels in society. This will require significant shifts in the ways in which they are organised, staffed and funded. ${ }^{10}$

On the way back from Hong Kong I had the privilege of visiting the new National Law School in Bangalore which has been established by the Bar Council of India as a model law school, designed to help to upgrade the whole system of legal education in India. ${ }^{11}$ It approximates very closely to the multi-functional model for which I argued in my paper. To be sure, it gives pride of place to an intensive, imaginatively conceived five year first degree that integrates a multidisciplinary approach to legal study with clinical experience, placements and skills training. But that is only one part of its activities: already it has organised intensive refresher courses for law teachers, judicial training seminars, legal literacy courses for women and legal awareness programmes for community workers and others. It is producing a law journal and a legal information service about current law, advanced continuing legal education workshops and it is developing plans for distance education using modern techniques and technology. The National Law School promises to become a model not only for India, but for many other countries in the Commonwealth, not least because it is relatively modestly financed. 
One final point on recent trends. "The knowledge explosion” in law is not confined to standard and core subjects. Options have proliferated at undergraduate and postgraduate level. Thirty years ago the standard three year LLB curriculum rarely listed more than twelve to fifteen subjects; today some extend to over fifty. In 1965 about 30 subjects were offered in the London LLM; today it lists over 100 and also makes provision for taking cognate subjects in other disciplines that are not listed. This proliferation of subjects has coincided with the shift from emphasis on knowledge to skills and with other demands on curriculum while the standard time allowed for primary legal education has generally remained unchanged. The result is that the pressures to overload the curriculum have become immense. The situation is exacerbated where a switch to skills teaching at the vocational stage is accompanied by increased demands on coverage at the academic stage either through a formal extension of the number of "core subjects" or by informal pressures on students to select "practical" options. In some countries the danger of a knowledge backlash is very real. This is one area in which clearly contradictory messages are being sent down from above to our students. For while undergraduates are encouraged to cover more and more areas of substantive law, teachers in some vocational courses often say that they prefer non-law graduates with uncluttered minds to law graduates who lack basic intellectual and research skills such as the capacity to express themselves clearly, to construct an argument or to use a law library. The vocational teachers and the profession cannot have it both ways. The arguments against coverage have been well summarised by Peter Wesley-Smith:

(M)ere acquisition of legal knowledge in law school is of little value to a practitioner because that knowledge (a) can only be a tiny portion of the whole, (b) can be understood only superficially, (c) is easily forgotten or only partially or inaccurately remembered, (d) is rarely needed in practice in the form in which it is learned, (e) is likely to be quickly outmoded and thus dangerous to rely on, and (f) is of little use when new problems arise to be solved. ${ }^{12}$

There are encouraging signs that university and polytechnic law teachers are responding by insisting that "we are in the skills business too" and that the main function of the academic stage is to develop intellectual skills. ${ }^{13}$ This amounts to a reassertion of some of the basic values of classical liberal education. But if the law 
teachers are to be believed by their students these values need to be reinforced rather than undermined by the practising profession.

\section{MAKING THE TRUISMS COME TRUE}

Many recent developments in legal education concern the structure, functions and financing of legal education systems as a whole and the legal educational needs of non-lawyers. Most of these recent trends and the arguments for a broadened conception of legal education in society are directly relevant to the narrower topic of the professional formation and development of practising lawyers in the private and public sectors. For they reflect a growing realization that the general educational truisms enumerated at the start need to be taken seriously not only at the level of primary legal education but also in respect of such matters as continuing legal education, specialisation, retraining, recertification and multidisciplinary and international practice. Each of these topics raises difficult practical issues of policy and implementation that are beginning to receive detailed attention. Fundamental to all of them are the attitudes and expectations of the recipients and purveyors of legal education. These attitudes and expectations are most likely to be formed at the early stages of the process ... in systems on the Gower model at the academic and vocational stages.

In the limited space available I can only sketch some of the implications of these truisms as they bear on the who, the when and the how of professional education.

(a) Legal education for whom? The most obvious implication of the idea that education is a lifelong process is that it concerns not only undergraduates and intending practitioners, but also the recently qualified, leaders of the bar and senior judges. It applies to lawyers in the public sector and in industry as well as to private practitioners. How far the later stages can and should be left to self education will be touched on briefly below. One reason for welcoming the belated development of institutionalised continuing legal education is that it offers by far the best hope of relieving pressures on the overcrowded curriculum at the primary level. It should be a further truism that the basic formation of a professional lawyer is at least a ten-year process which does not stop at the point of admission and that law students should be encouraged not to try to cross 
bridges before they come to them. When I tell this to my first year students, I sense that they do not really believe me.

Less obvious perhaps is the question of access: who does and who does not have the opportunity to become lawyers? One of the more important conclusions of a recent Commonwealth symposium on the subject ${ }^{14}$ is that in systems where there is strong competition for places in law school, the criteria for admission have very little to do with suitability for legal practice. Another lesson of that exercise was that systems with multiple routes of entry (via degrees other than law, external degrees, apprenticeship, conversion courses, overseas qualifications etc.) tend to present far fewer barriers to access than do those which require a full-time law degree as a necessary qualification for practice. I admit that I used to be opposed to non-law graduate entry and looked down on external degrees, but as a result of this exercise I am converted to "open study"15 and multiple routes to qualification as providing opportunities for many suitable and highly motivated people who have contributed much to legal practice. Another lesson of the access study is that changes in law school admissions policies by themselves are unlikely to make a significant contribution to problems of access unless backed by other measures such as access courses, adjustments to curriculum and general flexibility in educational provision.

(b) Continuing legal education and specialisation. Our truisms suggest that continuing legal education should be a life-long matter, but that most of it should take the form of selfeducation. Some of the main issues in this area relate to how far it should be required or controlled, what is the optimal mix of learning by experience and formal study, and how much time it needs or deserves.

A Sellar and Yeatman history of continuing legal education (CLE) might read as follows: Stage one was characterised by occasional lectures on recent developments in legislation and case law designed to help practitioners to keep up to date with legal doctrine in a relatively painless way. Stage two involved rather more substantial half-day or even one-day “courses”, especially for the recently qualified, often designed to fill in gaps in their basic training in, for example, office management, communication skills, 
trial advocacy or substantive law subjects they had not "covered” in their formal studies. This mode sometimes runs over into rather more high-powered and expensive workshops or conferences involving star speakers, glossy handouts and heavy lunches ... at the top end of the market extending to whole weekends in Oxbridge colleges or other congenial settings. In North America the CLE industry now includes use of distance-learning devices, such as audio-cassettes, home-videos and specially prepared materials of varying degrees of sophistication. Such devices are beginning to catch on in richer jurisdictions within the Commonwealth. At their best each of these modes can meet real needs in a quick, efficient and congenial way. They often adequately serve the functions of updating, keeping in touch and refreshment within existing frameworks. It is less clear that the quick fix, canned wisdom or heavy lunches are suitable for more ambitious objectives of breaking bad habits, introducing new skills, building specialisms or moving beyond competence to excellence.

The main limitation of all of these methods is that they make too many concessions to pressures of time. They proceed on the assumption that busy professionals are too busy to devote more than a few hours a year to CLE, including reading, listening or viewing on one's own. From an educational point of view it is difficult to see how it is possible for even the most sophisticated, intelligent and interested learners to deal in depth or even adequately with new ideas or approaches and their implications and applications without time for reading, critical reflection and exercise. The same considerations apply with even greater force to specialisation. ${ }^{16}$ If certification of specialists is to develop within legal professions it would be very strange if this were to be left entirely to learning by experience or if it were to be tested mainly or solely by outmoded forms of examination. This would be to revive in a mischievous way the false dichotomies between academic and practical or theory and practice. And it is doubtful whether any profession can stay learned solely on a diet of canned learning. In short, to echo Holmes, we have too little theory within CLE rather than too much. ${ }^{17}$

I am well aware that any suggestion that Jurisprudence should have a place in CLE is likely to be greeted by scepticism, if not derision, by most practitioners. As a legal theorist I am also 
vulnerable to charges of special pleading. So let me make it clear that I am not arguing for refresher courses on Austin and Bentham or updates on the latest fashions in legal semiotics or autopeiosis. Nor do I think that most existing postgraduate courses are necessarily well-suited to providing the academic component of specialist training. High-grade CLE will require changes in academic practice as well as the attitudes of practitioners.

Let me illustrate what I have in mind by some practical examples drawn from recent developments in legal theory. One of the central concerns of the most prominent of contemporary jurists, Ronald Dworkin, is with what constitutes a valid and cogent argument on a question of law in a hard case. ${ }^{18}$ Dworkin's own concerns are philosophical, but his ideal judge, Hercules, provides a model for argument which any judge or advocate who accepts his premises might seek to emulate. Dworkin's chief critics include Judge Bork and Judge Posner who offer rival models of legal argumentation. At present many undergraduates learn about Hercules in courses on Jurisprudence, but so far as I am aware few practical courses are directed to teaching how to construct Herculean arguments (or alternative kinds). One reason for this is that nearly all formal skills teaching is at an introductory level, concerned with competence rather than excellence, ${ }^{19}$ and most courses on advocacy concentrate more on presentation rather than on construction and criticism of arguments. ${ }^{20}$

A second example relates to evidence, proof and fact handling. The last ten years have seen a remarkable revival of theoretical interest in this area. Two aspects of this "new evidence scholarship" 21 are directly relevant here. First there has been a series of debates about probabilities and proof and the application of Bayes' theorem and other theories of probability to arguments about disputed questions of fact. While some of the debates are indeed rather recondite, the use of statistical arguments in court and in other contexts is developing fast in the United States ${ }^{22}$ and is likely to spread to many other parts of the common law world well before the year 2000. A century ago Holmes argued that the lawyer of the future needed to have a mastery of economics and statistics, ${ }^{23}$ but in my experience most lawyers are innumerate and most law students are terrified of figures. It is likely that Holmes' dictum will be incorporated in standard conceptions of competence by the year 
2000. It is extremely unlikely that competence in these areas can be developed by quick fixes of CLE.

The new Evidence scholarship is also concerned with a number of other topics that are relevant to the daily work of practising lawyers and judges, such as methods of ordering large masses of data and complex arguments, story-telling and the use of computers in fact investigation. ${ }^{24}$ Some of these deserve to be at the core of primary legal education, but it will be difficult in practice to make space for them; all involve an admixture of theory and practice.

One pattern that emerges from many of these new developments is that there is a growing convergence between new trends in professional training and traditional values of liberal education, ${ }^{25}$ especially in relation to such questions as: what constitutes excellence in respect of legal skills? how is it best fostered? This convergence is one reason why those old educational truisms need to be taken seriously by all who are involved in the process. The starting-point for this is a vision of the total enterprise of legal education that embodies these ideas and is reinforced by messages from those who are in a position to influence attitudes and expectations such as those responsible for professional examinations, recruitment and post-qualification training. The kind of message I have in mind is embodied in a mundane document produced by one of the newer institutions of legal education in the Commonwealth, the Practising Law Institute of Xanadu. ${ }^{26}$ This is what they write to those to whom they have offered places on their vocational course:

At the Xanadu Practising Law Institute we accept graduates from a variety of educational backgrounds. They come to us with quite different stocks of specialised knowledge of varying degrees of freshness. What we expect of all our entrants is a command of basic intellectual skills and a capacity to work on their own. In particular we expect all entrants to be able to express themselves clearly and precisely, both orally and in writing; to distinguish the relevant from the irrelevant; to construct and criticise an argument on a question of fact or law; to make intelligent use of a law library; and to get up or refresh their memory on a specific legal topic quickly and efficiently on their own.

From the first day of term we shall take for granted an up-to-date grasp of the basic concepts and general principles concerning the topics listed in Note 1, including a working familiarity with the statutes listed in Note 2. If you are unfamiliar with any of these or if your memories about them are a bit rusty, you are asked to fill in the gaps and refresh 
your memory before the start of term. You are also asked to bring with you draft answers to any two of the problems set out in Note 3.

Note 1 contains a quite short list of selected topics (falling mainly but not exclusively within the area of the local "core" subjects) that will be the basis of preliminary exercises in the first weeks of the course. Note 2 contains a list of not more than ten important statutes that will be relevant to the early exercises. It includes at least two statutes that have come into force or have been amended in the last year. Note 3 contains some problem situations raising issues that will test basic library skills. They are also directly relevant to practical exercises scheduled in the first weeks of the course.

I have suggested that there is a strong convergence between recent developments in skills training and some central values of liberal education in that they both give a high priority to transferable intellectual skills rather than to particular techniques or specific knowledge, especially in the primary stages. If this is correct, the model, assumed in the letter, of an intellectually mature, liberally educated law graduate might win widespread support within all sectors of legal education and training. Insofar as it embodies an acceptable set of expectations not only for future practitioners but also for recipients of continuing legal education, it is worth asking of any jurisdiction: to what extent do our law graduates fit this model? To the extent that they do not, why is this so? Are there any current practices (in bar examinations, criteria for recognition of law degrees questions asked at interview, CLE practices etc.) which undermine these aspirations? And what might be done positively to foster them? Let us hope that by the year 2000 academics and practitioners will be singing in unison and that our students will have got the message.

* Quain Professor Jurisprudence, University College, London; Executive Chairman, Commonwealth Legal Education Association (hereafter CLEA). (C) 1992. (1992) 3 Legal Educ Rev 1.

1 This paper was prepared for the Ninth Commonwealth Law Conference, 1990. It builds on and develops some themes in an earlier paper, "Developments in Legal Education in the Commonwealth: Beyond the Primary School Model”. This was presented at a conference to commemorate the twentieth anniversary of the Faculty of Law of the University of Hong Kong and was published in R Wacks ed The Future of Legal Education and the Legal Profession in Hong Kong (University of Hong Kong, 1989) and in (1990) 2 Legal Educ Rev 35. The opinions expressed in these two papers are my own and do not necessarily represent the policy of CLEA.

2 Heads of University Law Schools Law as an Academic Discipline (London, unpublished, 1984). An abbreviated version was published in the Society of Public Teachers of Law, Newsletter, Summer, 1984. The author was chairman of the working-party that prepared the Report. The account in the text adds a 
few Commonwealth glosses to the Report, which was confined to England and Wales.

3 Professor Gower tells me that the decision to provide the vocational stage outside university law faculties in Ghana and Nigeria was taken before he became involved in developing local legal education in those countries. A similar structure was adopted in other jurisdictions where he served as a consultant, including Hong Kong, Uganda and, later, England and Wales (on which see Report of the Committee on Legal Education (Ormond Report) 1971 Cmnd 4594, HMSO London. Part of my argument in this paper and its predecessor (supra note 1) is that this kind of rigid structure tends to marginalise the contributions of professional law teachers after the primary stages and to entrench unhealthily sharp distinctions between "theory" and "practice". This argument is not intended as a criticism of decisions taken in Ghana and Nigeria thirty years ago, still less of Jim Gower's many contributions to legal education and training in the Commonwealth.

Many of these developments are described in the CLEA Newsletter. On critical legal studies, see M Kelman A Guide to Critical Legal Studies (Cambridge, Massachusetts: Harvard UP, 1987); on in-house trainers, see Commonwealth Directory of In-House Training Professionals, Commonwealth Institute of Legal Education and Training (CILET), (Windsor, Ontario, 1988); on distance learning, see J Goldring, Distance Teaching in Law: A Proposal for Commonwealth Co-operation, (1989) 57/58 CLEA Newsletter, Annex 11; on access, see R Dhavan, N Kibble \& W Twining eds Access to Legal Education and the Legal Profession (Butterworths and CLEA: London, 1989); on skills, see $\mathrm{N}$ Gold, K Mackie \& W Twining eds Learning lawyers' Skills (Butterworths and CLEA: London, 1989) and J Watt ed The Legal Skills Sourcebook (Sydney, NSW and CILET, 1989); on international mobility of lawyers, see C McLachlan in Dhavan, Kibble \& Twining, id at ch 14; on autopeiosis, see G Teubner Autopoietic Law (Berlin: Walter de Gruyter, 1988). A lot is likely to be heard of Records Management in the nineteen nineties. It is significant that the Association of Commonwealth Archivists have changed their title to Association of Commonwealth Archivists and Records Managers (ACARM). They have recently turned their attention to legal records.

Problems of law in multi-lingual societies were a recurrent theme of the Hong Kong conference, supra note 1 . The best study to date of the implications of such problems for legal education is M Cooray Changing the Language of the Law: the Sri Lankan Experience (Quebec: Les Presses de L’Université Laval, 1985). See especially supra note 1.

7 "The case for law" is well argued by K Patchett in The Role of Law in the Development Process, (1987) 48 CLEA Newsletter 33.

8 Supra note 2.

9 Supra note 1.

10 Id. The idea was first developed in Legal Education in a Changing World (New York: International Legal Center, 1975).

11 I am grateful to the Director, Dr N Mhadava Menon, and his colleagues for the information in this paragraph. Further details may be obtained from the Director, National Law School of India, Central College Compound, Bangalore 560001, India.

12 P Wesley-Smith, Neither a Trade nor a Solemn Jugglery: Law as Liberal Education, in Wacks supra note 1, at 62.

13 J McFarlane, M Jeeves \& A Boone, Education for Life or Work? (1987) New Law Journal, Sept 4, 835-6; W Twining, Legal Skills and Legal Education, (1988) 22 The Law Teacher 4.

15 From its early days, almost 150 years ago, the London External System was 
based on the twin principles of "open entry" (no numerus clausus, i.e. all who satisfied General Entrance Requirements were eligible to register) and "open learning" (i.e. no prescribed courses or methods of study). The first principle seems to have served the purpose of extending educational opportunity admirably; the second has been more controversial. Until recently the University of London served only as an examining and accrediting body and offered no instruction and little guidance to candidates. In recent years the policy has been modified to allow some direct instruction, but the principle of "open learning" still operates.

In the 1989 White Paper on Legal Services (Cm. 740), the Lord Chancellor recommended that the proposed Advisory Committee should include among its functions: 'To offer advice on whether schemes for areas of accredited specialisation put forward by the professional bodies or other organisations are likely to serve the efficient delivery of legal services to the public; and to consider on its own initiative whether any new areas of accredited specialisation are necessary; and to advise the relevant organisations accordingly.” (7.6(iv)).

O W Holmes Jr, The Path of the Law, (1897) 10 Ham L Rev 457

18 R Dworkin, Hard Cases in Taking Rights Seriously (London: Duckworth, 1977) and Law's Empire (London: Fontana, 1986).

19 At present nearly all skills teaching involves a very limited number of introductory exercises (see Gold, Mackie \& Twining supra note 4). It is significant that the Council of Legal Education in London makes no higher claim for its new vocational course for intending barristers than that it is a preparation for pupillage. Success in the course does not per se certify minimum competence; at present in most cases the development of excellence in respect of skills is still left almost entirely to "learning by experience".

20 The Ontario Advocates' Institute has recently conducted an interesting enquiry into what is thought to constitute excellence in advocacy. While highly regarded advocates were found to be rather inarticulate about their skills, the study concluded that preparation is the main key to effective advocacy. This might seem to underline the obvious, but most courses on advocacy have concentrated more on presentation than preparation. See Gold, Mackie \& Twining supra note 4 at 323-4.

21 The phrase was coined by R Lempert (1986) 66 Boston U L Rev 439. For a critical discussion, see W Twining, Rethinking Evidence (Oxford: Blackwell, 1990), ch 12.

Lempert, supra note 21 , cites figures that indicate that about $4 \%$ of reported District Court opinions in the United States between 1960 and 1979 involved some use of statistical evidence and that this was on a steadily rising curve. See generally, Sir R Eggleston Evidence, Proof and Probability, 2nd ed, London: Weidenfeld and Nicolson, 1982) and DW Barnes, Statistics as Proof (Boston: Little, Brown, 1983).

Holmes, supra note 17.

24 See generally supra note 21 and P Tillers \& D Schum, Charting New Territory in Judicial Proof: Beyond Wigmore, (1988) 9 Cardoza L Rev 907. Supra note 13.

26 On the Xanadu Law School, see Dhavan, Kibble \& Twining, supra note 4 at 1 and 32 note 1. 